\section{Dating of Conchas River Sediments, New Mexico}

THERE is an interesting sedimentary deposit along the Conchas River in San Miguel County, New Mexico, a few miles above the point at which the river enters Conchas Lake. The name Conchas is derived from the well preserved specimens of freshwater clam shells, class Pelecypoda, family Unionidae, which are buried at a depth of about 4 feet in the sediments. In the same area are found Indian artefacts, and in one terrace a fireplace was found buried 4.5 feet below the surface. The fireplace consisted of a horizontal arrangement of flat rocks on which were deposited pieces of charcoal. The sholls and charcoal were sampled for carbon-14 dating.

Samples from the same terrace were taken for dating by ion exchange ${ }^{1}$. Soil samples were taken at intervals of 4 inches for the first 2 feet beneath the surface and then at intervals of 1 foot to a depth of 5 feet. The samples were screened and the fine fraction (that which passed through a screen of 200 meshes per inch) was retained for analysis.

The exchangeable cations were removed from the soil by extracting with a 1 M solution of ammonium acetate $^{2}$, which was mixed in the ratio of $10: 1$ by weight with the soil, shaken for $1 \mathrm{~h}$, allowed to stand $24 \mathrm{~h}$ and then filtered off and analysed for sodium and potassium (Beckman DU flame spectrophotometer). The results are reported in equivalents of cation per $100 \mathrm{~g}$ of soil in Table 1 and shown plotted in Fig. 1.

Table 1. Na and $\mathrm{K}$ CONTENT OF CONCHAS RIVER SEDMEN'

$\begin{array}{cccc}\begin{array}{c}\text { Sample } \\ \text { No. }\end{array} & \begin{array}{c}\text { Depth below } \\ \text { surface (inches) }\end{array} & \begin{array}{c}\text { Na (equiv. } / 100 \mathrm{~g}) \\ \left(\times 10^{4}\right)\end{array} & \mathrm{K} \text { (equiv./100 g) } \\ \left(\times 10^{4}\right) \\ 1 & 0-4 & 2 \cdot 6 & 5 \cdot 3 \\ 2 & 4-8 & 3 \cdot 3 & 7 \cdot 7 \\ 3 & 8-12 & 3 \cdot 7 & 9 \cdot 1 \\ 4 & 12-16 & 3 \cdot 5 & 7 \cdot 4 \\ 5 & 16-20 & 3 \cdot 6 & 8 \cdot 1 \\ 6 & 20-24 & 5 \cdot 1 & 1 \cdot \cdot 0 \\ 7 & 24-36 & 2 \cdot 8 & 10 \cdot 5 \\ 8 & 36-48 & 3 \cdot 3 & 7 \cdot 7 \\ 9 & 48-60 & 4 \cdot 4 & 4 \cdot 7\end{array}$

The plot of the data in Fig. I scems to indicate that the peak in concentration for both sodium and potassium is reached at a depth of about 2 feet. Schufle, Kottlowski and Beckhart ${ }^{3}$ calculated that 840 inches of rainfall were roquired to wash sodium or potassium through 1 foot of average soil. 'The average annual rainfall for the Conchas River arca, measured at the Bell Ranch Weather Station (64 year average), is 14.5 inches ${ }^{4}$. If we assume 90 per cent loss of rainfall to the soil due to run-off and evaporation losses, then only 10 per cent of the rainwater percolates through the soil, or 1.5 inches of water per year in the Conchas River area. The age of this sediment is then calculated to be

$$
\frac{840 \mathrm{inch}}{\mathrm{l} \cdot 5 \text { inch } / \mathrm{yr}} \times 2=1,100 \mathrm{yr}
$$

We estimate that the probable error in this method of dating is \pm 20 per cent, so we can place the age of the Conchas River sediment at $1,100 \pm 200 \mathrm{yr}$.

The charcoal from the buried fireplace was dated at $860 \pm 120{ }^{14} \mathrm{C}$ years BP by Geochron Laboratories, Cambridge, Massachusetts, and a sample of the clam shells buried in the same area was dated at $765 \pm 105{ }^{{ }^{4} \mathrm{C}}$ years BP. According to this laboratory it is not unusual for shell material to give dates which are somewhat younger than associatcd charcoal, partly as a result of ground wator activity and the possibility of exchange of dissolved carbonate between the shell and the groundwater, so we may take the charcoal date as somewhat more reliable. The agreement of this date with the date obtained by our ion exchange method is reasonable.

It might be suggested that the figure of 90 per cent for loss of water to the soil by run-off and evaporation losses

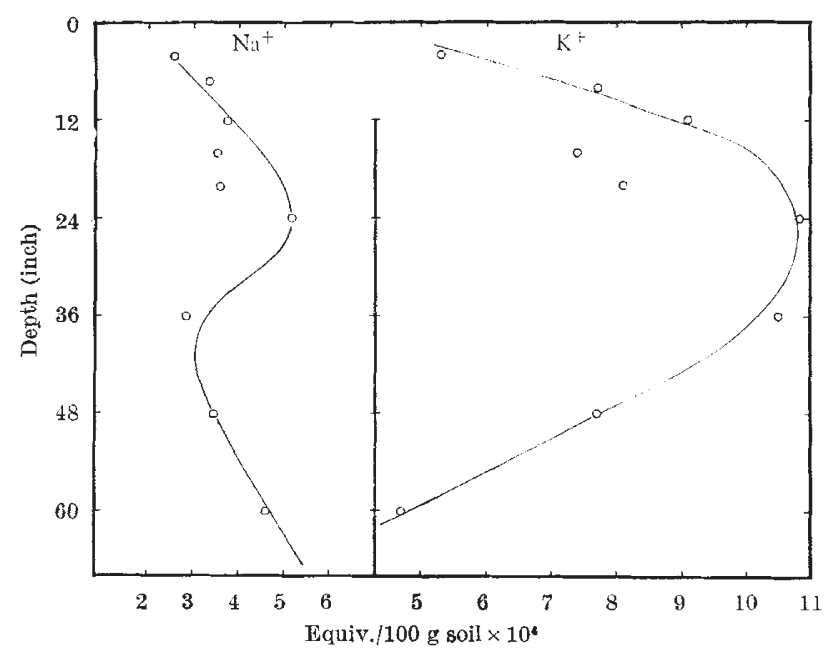

Fig. 1. Depth versus concentration, Conchas River terrace.

is the weakest point in the calculation of the age of sediments by the ion exchange method. This run-off figure was first estimated by Schufle and Hassan ${ }^{1}$ from comparison of ion exchange data from a terrace along the Rio Grande near Socorro, New Mexico, with a ${ }^{14} \mathrm{C}$ date obtained by $R e^{5}$ on a similar terrace from charcoal buried within the terrace. It might bo useful to recalculate the percentage run-off from the ion exchange data on this present Conchas River sediment and its corresponding ${ }^{14} \mathrm{C}$ date. This is

$$
\frac{840}{14 \cdot 5-14 \cdot 5 X} \times 2=860 \mathrm{yr}
$$

where $X$ is the fraction of the 14.5 inches per year average annual rainfall which is lost to the soil by run-off and evaporation. We can calculate then that if 87 per cent of the rainwater is lost by run-off and evaporation the ion exchange date on tho Conchas River sediment will correspond exactly with the ${ }^{14} \mathrm{C}$ date. Perhaps further investigations should be made to locate other arid zone sediments which can be dated by both the ion exchange method and the ${ }^{14} \mathrm{C}$ method. More reliable figures for losses of rainfall by run-off and evaporation might be arrived at thereby.

\section{J. A. Schufut Gilbert Brassert}

Department of Chemistry,

New Mexico Highlands University, Las Vegas, New Mexico 87701.

Rccelved May 27, 1969

${ }^{2}$ Schufle, J. A., and Hassan, A., Texas J. Sci., 15, 293 (1963).

${ }^{2}$ Peech, M., Soil Sci., 59, 25 (1945). "Schufle, J. A., Kottlowski, F. E., and Beckhart, R. H. C., Texas J. Sci., 18,

4 White, R. M., Weather Bureau, US Dept. Comm. Ann. Summ., 68, No. 13 (1965).

Suhe, Robert V., J. Geol., 70, 151 (1962).

\section{Additional Metalliferous Sediments in the Red Sea}

Geochemical investigations are being undertaken of a series of gravity cores collected in the Red Sea from the RRS Discovery in 1963 (Fig. 1). The chief interest of these cores is the similarity between the shipboard description of core 5233 and those of cores from the metalliferous brine deposits of the Atlantis and Discovery 